\title{
Macrophyte Diversity as a Response to Extreme Conditions in the Post-Mining Lakes of the Muskau Arch (West Poland)
}

\author{
Małgorzata Oszkinis-Golon ${ }^{1}$, Marcin Frankowski ${ }^{2}\left(\mathbb{D}\right.$ and Andrzej Pukacz ${ }^{3, *}$ (D) \\ 1 Institute of Biological Sciences, University of Zielona Góra, Prof. Z. Szafrana 1, 65-516 Zielona Góra, Poland; \\ gosiaoszkinis@wp.pl \\ 2 Faculty of Chemistry, Adam Mickiewicz University, Uniwersytetu Poznańskiego 8, 61-614 Poznań, Poland; \\ marcin.frankowski@amu.edu.pl \\ 3 Collegium Polonicum, Adam Mickiewicz University, Kościuszki 1, 69-100 Słubice, Poland \\ * Correspondence: pukacz@europa-uni.de
}

Citation: Oszkinis-Golon, M.; Frankowski, M.; Pukacz, A.

Macrophyte Diversity as a Response to Extreme Conditions in the Post-Mining Lakes of the Muskau Arch (West Poland). Water 2021, 13, 2909. https://doi.org/10.3390/ w13202909

Academic Editor: Rui Cortes

Received: 6 September 2021

Accepted: 14 October 2021

Published: 16 October 2021

Publisher's Note: MDPI stays neutral with regard to jurisdictional claims in published maps and institutional affiliations.

Copyright: (c) 2021 by the authors. Licensee MDPI, Basel, Switzerland. This article is an open access article distributed under the terms and conditions of the Creative Commons Attribution (CC BY) license (https:/ / creativecommons.org/licenses/by/ $4.0 /)$.

\begin{abstract}
The pit lakes localized in the eastern part of the Muskau Arch (Western Poland) developed as a result of lignite mining at the turn of the 20th century. The formation of the lakes varied over time and was determined by many hydrogeochemical and biological factors, which resulted in very diverse ecosystems. Thirty of these lakes were studied in the vegetation seasons of 2016 and 2017. The aim of the study was to identify the main factors influencing the diversity of macrophyte vegetation growing under very extreme and diversified habitat conditions. Therefore, in each lake the numbers of macrophyte species and communities were determined, and the water was characterized by 26 physico-chemical parameters and $\mathrm{Chl}$ a. Additionally, the genesis, age, area and maximum depth of each lake was determined. The results showed high diversity of habitat conditions. Based on the physical and chemical water properties, four different clusters of lakes were distinguished. The multiple statistical comparisons showed that the main factors responsible for lake differentiation were $\mathrm{pH}$, water mineralization and to a lesser extent, nutrient concentration and water transparency. The physico-chemical differentiation was reflected in the significant differences in the number of species, number of communities, maximum vegetation extent and amount of chlorophyll-a per lake. The correlational analyses confirmed significant relationships between habitat conditions and macrophyte flora diversity in the lakes. Some macrophyte species were found in very extreme environments not previously reported in the literature. Our results showed that in addition to natural processes affecting species diversity in the lakes, the negative impact of anthropogenic pressures (neutralization and fertilization of the water), which leads to the degradation of their unique character, is also an important factor.
\end{abstract}

Keywords: pit lakes; physico-chemical differentiation; macrophyte diversity; succession; neutralization; Muskau Arch

\section{Introduction:}

The extraction of natural resources has had a significant influence on the natural environment for many decades, including the development of post-mining lakes. In time, these lakes became integral parts of post-industrial landscapes, creating very diverse habitats in terms of morphometric structure and water chemistry [1].

Their current characteristics mostly depend on the material that was being extracted (e.g., brown coal, lignite, clay, sand, gravel, building stones or peat), as that determines the amounts and types of minerals leaching into the environment. As such, it significantly affects both the physico-chemical parameters and coloration of the resulting pit lake [2,3]. Moreover, the technique applied and timing of resource extraction influence these pit lakes, as they strongly determine the morphometric structure, and thus, the prevailing habitat diversity [4]. The processes occurring in these lakes differ in dynamics and scope depending on whether they were formed in place of open pit mines (open pit lakes) or 
underground mines (sink hole lakes) [5,6]. The time in which the mining took place has a significant impact on the formation of depressions, which fill with water to form the lakes. In the oldest underground mines, sinkholes have formed, which gradually filled with water over many years, or even decades. In younger mines, on the other hand, where opencast methods were used, the process of filling with water was faster and the lakes formed did not significantly change their bathymetry [3].

Lakes formed in sites of former lignite mining are dominant in Poland [7]. Their waters are characterized by very low pHs (usually as a result of decay of pyrite), high mineralization and high concentrations of heavy metals [8,9]. The main factor determining the physicochemical conditions in these lakes is oxidation of iron sulfide, which is present in in lignite and shale residues left in the drainage basins ([3] and references quoted therein). The main products of this process are iron hydroxide, sulfate ions and hydrogen ions. The first one causes the characteristic reddish-brown color of the water in most of these lakes. The latter two are the substrates for a strong sulfuric acid solution responsible for the acidification of the water. An additional effect of water acidification is the leaching of toxic compounds (aluminum and heavy metals) from the substratum. Consequently, conditions in many post-mining lakes hamper the development of living organisms, which reduces the speed of evolutionary transformations therein [10].

The main factors influencing the variability of lignite lakes are the physico-chemical conditions. The changes at the abiotic level (mainly reduction of acidity and mineralization) enable the development of favorable conditions for the appearance of the first biocenoses [11]. This leads to the establishment of secondary succession processes, which in many respects resemble those in natural lakes. As a consequence, emerging biocenoses also start to influence abiotic conditions in the lakes. The dynamics of progressive changes largely depend on the supply of water from the drainage area and the chemical composition of the eroded substrate forming the lake basin $[5,6]$. An additional factor affecting both the chemical diversity of the water and the variety and range of biocenoses may be the lake's morphometry, which mostly depends on its genesis [6]. However, unlike in natural lakes, it is subject to dynamic processes related to the sliding and erosion of working slopes and the bottom subsiding (greater depth) of lakes formed in previous underground mines [3].

As shown by contemporary studies (e.g., [1,6,10,12]), humans also significantly affect the processes occurring in pit lakes through secondary activities, such as liming the water or channeling wastewater into the lakes. Such things are done to use the lakes for recreation, agricultural and fishing purposes. The effects of these procedures are not only the irreversible neutralization of water, but also the acceleration of succession processes as a result of the growing nutrient pool. This way, the lakes lose their unique character much faster.

The above-mentioned processes considerably influence the development, growth and occurrence of macrophytes in pit lakes. In the first stage of lake formation, they are pioneer organisms and one of the main sources of organic matter in the littoral zones. They are also an important component of food webs, and as decomposed organic matter, a source of valuable nutrients to autotrophs. In addition, macrophyte communities, both in rushes and underwater, can provide refuge for newly emerging animals. In the already formed ecosystems, the submerged vegetation serves, i.a., as nutrient traps, increases the sedimentation, stabilizes the sludge and prevents its resuspension $[13,14]$. In turn, reed bed vegetation is important mostly as a barrier protecting the reservoir from erosion or excessive supplies of allochtonous nutrients and organic matter from the drainage basin [15].

The Muskau Arch is one of greatest clusters of post-mining lakes in Poland, and by extension, Europe. In the region there are lakes that formed at the turn of the 20th century as a result of lignite extraction, which was often coupled with the extraction of clay and sand [16]. The details of the hydrochemical and hydrobiological properties of the lakes located within the Muskau Arch are still poorly recognized. The main reason for this is that the lakes are located in difficult-to-access terrain (hilly and densely forested). However, 
this also means that many of the lakes have never been further transformed by human activity, maintaining their original character.

The aims of the research were to: (a) characterize the diversity of the post-mining lakes of the Muskau Arch at the biotic level through assessing the macrophytes growing in very extreme conditions, and (b) identify the main factors influencing the diversity at the level of flora and vegetation. We hypothesized that the diversity of macrophyte vegetation of the Muskau Arch pit lakes not only reflects the physico-chemical properties of water, but also human-induced transformations.

\section{Study Area and Methods}

\subsection{Study Objects}

The study was performed during the summers of 2016 and 2017 (July and August) in 30 pit lakes (15 each year) located in the Muskau Arch (West Poland, Figure 1). The lakes are of post-mining origin (mostly lignite) and belong to the so-called Anthropogenic Lake District [5]. As was shown in previous studies (e.g., [4,11]), the lakes are diversified as regards their bathymetry and the physico-chemical properties of their waters. This applies in particular to $\mathrm{pH}$ and water mineralization, which also have significant impacts on other water parameters. The lakes were randomly selected for this study to be representative of the entire area, especially in terms of distribution and morphometric structure. The detailed locations and characteristics of the lakes were presented in a study by Pukacz et al. [4].

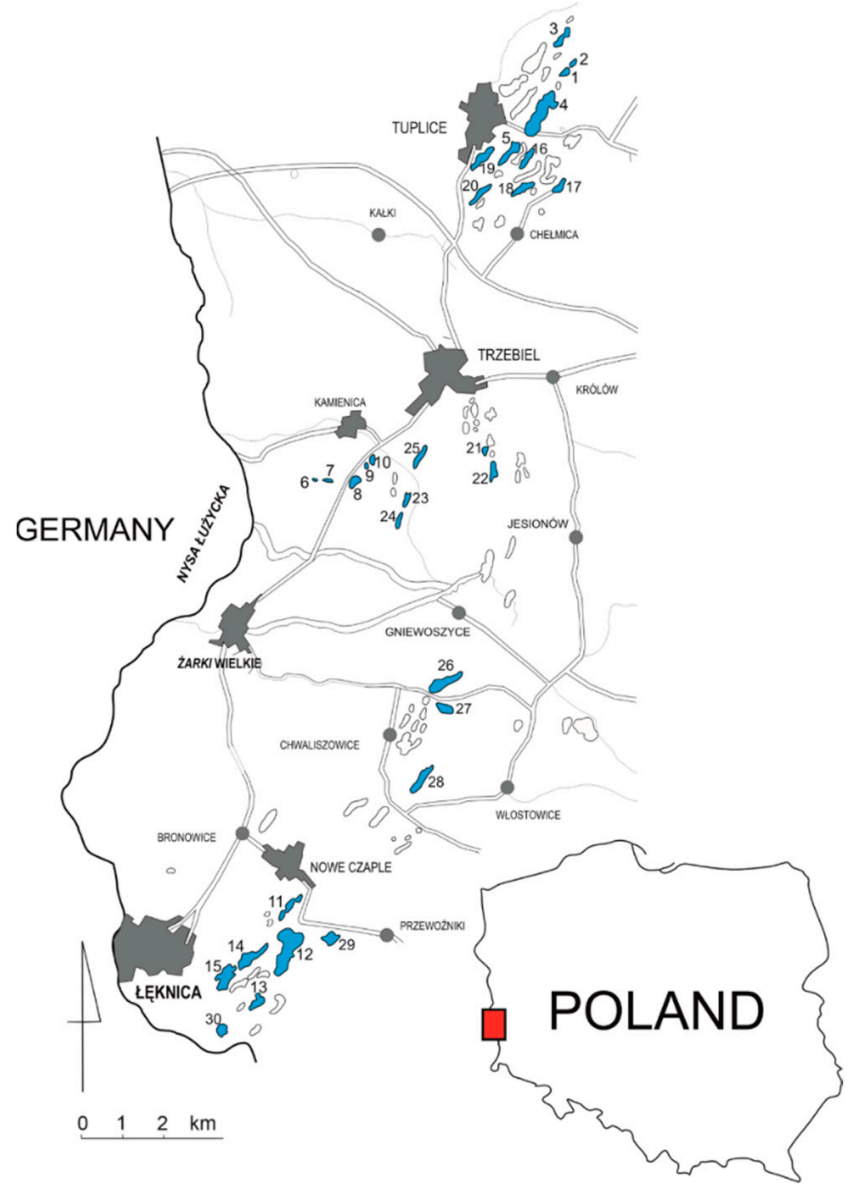

Figure 1. The locations of the investigated lakes (marked in black and numbered), originally published in Pukacz et al. 2018 [4].

Before each survey, a Lowrance Mark 5x Pro fish finder was used in all lakes to determine their maximum depths and any potential bottom anomalies. In addition, vegetation- 
free sampling sites for physicochemical analysis were selected. The surface area of each lake was determined using maps and satellite images and Geoportal tools.

\subsection{Study of Vegetation}

In order to determine the phytocoenotic structure of aquatic and reed bed vegetation of the studied lakes, the Central European method of phytosociological relevés by Braun-Blanquet [17] was used in combination with the transect method. The transects were perpendicular to the shoreline and localized in sites that were unaffected by human activity. The parts of the transects between the shoreline and the end of the reed-belt were mapped by wading, and we integrated all the species in the central part of the subsequent community. From the end of the reed-belt towards the center of the lake, the relevés were taken from the centers of the communities, until the onset of the maximum depth of vegetation. The number of transects (from 3 to 8 ) and their lengths (from 3 to $17 \mathrm{~m}$ ) varied and were dependent on the lake morphometry (area, depth and bottom slope), and the individual complexity of the vegetation. The widths of the transects varied from 3 to $4 \mathrm{~m}$, and they were dependent on the spatial structure of the vegetation. The submerged vegetation investigations and the maximum depth extent measurements were performed by snorkeling (for the deep water) or from a boat, using a small anchor with a calibrated rope (for the shallow water and in case of turbid water).

Phytosociological relevés were taken so as to grasp all the communities of water and reed bed vegetation occurring within the lake area. To avoid the transitional zones with terrestrial vegetation, the phytosociological relevés were taken from the shoreline boundary. In order not to miss any species or communities, additional surveys were also performed outside the transects and relevés. Based on these vegetation surveys (both within the relevés and additional ones), three macrophyte variables (number of communities, number of species and maximum depth of vegetation) were derived and used for statistical analyses.

\subsection{Study of Physico-Chemical Parameters}

All the lakes were characterized in terms of the same set of physico-chemical parameters measured in the surface water: $\mathrm{pH}$, electrolytic conductivity, color, hardness, $\mathrm{Ca}^{2+}, \mathrm{Na}^{+}$, $\mathrm{K}^{+}, \mathrm{Mg}^{2+}, \mathrm{Cl}^{-}, \mathrm{NH}_{4}{ }^{+}, \mathrm{NO}_{3}{ }^{-}, \mathrm{NO}_{2}{ }^{-}$, total nitrogen (TN), $\mathrm{N}_{\text {org. }}$, total iron $(\mathrm{Fe}), \mathrm{Fe}^{3+}, \mathrm{SO}_{4}{ }^{2-}$, $\mathrm{Al}^{3+}, \mathrm{Mn}^{2+}$, total carbon (TC), inorganic carbon (IC), total organic carbon (TOC), soluble reactive phosphorus (SRP), total phosphorus (TP), total sulphur (TS) and chlorophyll-a. The $\mathrm{pH}$, salinity and electrolytic conductivity (EC) were measured using Elmetron CX-701, and water transparency using Secchi disc (SD).

All the measurements and samplings were performed in the deepest, mostly central, vegetation-free point of each lake. The samples for chemical analyses were collected in one-liter bottles from the depth of $0.2 \mathrm{~m}$ below the surface, transported in a portable refrigerator and kept in a refrigerator $\left(\right.$ at $4{ }^{\circ} \mathrm{C}$ ) until the analyses were performed at the Department of Water and Soil Analysis, Faculty of Chemistry, Adam Mickiewicz University in Poznań. Additionally, a one-liter sample from the surface water was taken to determine chlorophyll-a concentration. The water was filtered immediately after the field surveys through Whatman GF/C filters, which were kept frozen. After thawing and acetone extraction, the samples were processed according to the method proposed by Golterman [18].

Concentrations of the total carbon (TC), inorganic carbon (IC) and total organic carbon (TOC) and total nitrogen (TN) were determined in the filtered samples by high-temperature combustion (HTC) using a Shimadzu TOC-L Total Organic Carbon analyzer (Shimadzu, Kyoto, Japan). For TN determination, the analyzer was equipped with a TNM-L TN unit (Shimadzu, Japan).

The concentrations of $\mathrm{Cl}^{-}, \mathrm{SO}_{4}{ }^{2-}, \mathrm{NO}_{2}{ }^{-}, \mathrm{NO}_{3}{ }^{-}$and $\mathrm{NH}_{4}{ }^{+}$ions were determined by the ion chromatography method with a conductivity detector (Shimadzu, Japan) using Thermo AS22 with AG22 columns. 
Color was determined by the visual method against the platinum scale. Total water hardness was determined by the versenate method. In order to determine $\mathrm{Ca}^{2+}$ and $\mathrm{Mg}^{2+}$ ion concentrations, a Metrohm ion chromatograph, 881 Compact IC Pro model (Metrohm, Herisau, Switzerland) was applied, using Metrosep C4 Guard as the guard column and Metrosep C4 150 as the separating column.

$\mathrm{Fe}^{3+}$ concentration was determined using the colorimetric thiocyanate method. The inductively coupled plasma optical emission spectrometer (ICP-OES) ICPE-9820 (Shimadzu, Japan) with a mini-torch was used for the qualitative and quantitative detection of $\mathrm{Na}^{+}, \mathrm{K}^{+}$, $\mathrm{Fe}, \mathrm{Al}^{3+}, \mathrm{Mn}^{2+}, \mathrm{TP}$ and TS. Prior to the analysis, the Sigma-Aldrich (St. Louis, MO, USA) periodic table mix 1 for ICP containing $10 \mathrm{mg} \mathrm{L}^{-1} \mathrm{Na}^{+}, \mathrm{K}^{+}, \mathrm{Fe}, \mathrm{Al}^{3+}, \mathrm{Mn}^{2+}$, TP and TS in $10 \%$ nitric acid (comprising HF traces) was used for the calibration of ICP-OES. In order to preserve the standard/sample conditions, the matrix match method was used.

The SRP in the water was determined by the molybdate method with ascorbic acid as a reducer. Prior to the analyses, the water samples were filtered through a rinsed $0.45 \mu \mathrm{m}$ pore size filter (Macherey-Nagel, Düren, Germany). As the SRP values in all lakes were below the method detection limit $\left(0.01 \mathrm{mg} \mathrm{L}^{-1}\right)$, this parameter was not considered in the analyses (According to standard: ISO 6878-1-1986, DIN 38405 D11-4).

So as to determine the habitat factors affecting the diversity of lake vegetation, the morphometric characteristics (maximum depth and area) and age (in years) were also taken into consideration in the analyses. The methodology for these variables and detailed physico-chemical data were presented by Pukacz et al. [4].

\subsection{Data Analysis}

Statistical analyses were performed using STATISTICA 12 (StatSoft Inc., Tulsa, OK, USA) software. The normality of the distributions of the analyzed variables and the homoscedasticity of the samples were tested with the Shapiro-Wilk and Levene tests, respectively. Different lake groups were compared using the Mann-Whitney $U$ test (for two groups), and multiple comparisons were conducted using the Kruskal-Wallis test followed by Dunn's post-hoc test for comparison of medians. $p<0.05$ was accepted as statistically sound.

Based on the physico-chemical data, the lakes were classified according to the cluster analysis (Ward's method, Euclidean distance). Prior to this analysis, simple factor analysis was performed to reduce the number of variables, and the data were logarithmically transformed so as to minimize the inconsistencies between the empirical distributions and the theoretical normal ones. The distinguished groups of lakes were compared as regards the water properties and macrophyte variables. Additionally, the speciation forms of nutrients that were highly interrelated were reduced to TC, TP and TN. A similar procedure was applied for $\mathrm{Fe}^{3+}$ and $\mathrm{SO}_{4}{ }^{2-}$, so only total $\mathrm{Fe}$ and TS were considered. Spearman's rank correlation test was applied to determine dependencies between the macrophyte variables (number of communities, number of species and maximum depth of vegetation) and the variables characterizing habitat conditions of the lakes (physico-chemical parameters, maximum depth and area and age).

As the analyses did not take into account temporal variability but only the current state of the lakes, year-to-year variability was not taken into account.

\section{Results}

\subsection{The Differentiation of Lake Water Properties}

In order to group the lakes into similar types with regard to physico-chemical parameters (SD, $\mathrm{pH}, \mathrm{EC}$, color, salinity, $\mathrm{Na}^{+}, \mathrm{K}^{+}, \mathrm{Ca}^{2+}, \mathrm{Mg}^{2+}, \mathrm{Cl}^{-}, \mathrm{Fe}, \mathrm{Al}^{3+}, \mathrm{Mn}^{2+}, \mathrm{TC}, \mathrm{TN}, \mathrm{TP}, \mathrm{TS}$, hardness), cluster analysis was used. The results of that analysis allowed us to identify two distinct groups of lakes, A and B (Figure 2), with completely different water characteristics. The results of Mann-Whitney tests showed statistically significant differences $(p<0.05)$ between these groups of lakes for all the parameters. Group A included lakes with low water visibility, relatively high $\mathrm{pH}$, low mineralization and relatively high nutrient concen- 
trations. Lakes in group B had greater water visibility, low $\mathrm{pH}$ values, high mineralization (reflected in EC values and the concentrations of most analyzed ions) and lower nutrient concentrations.

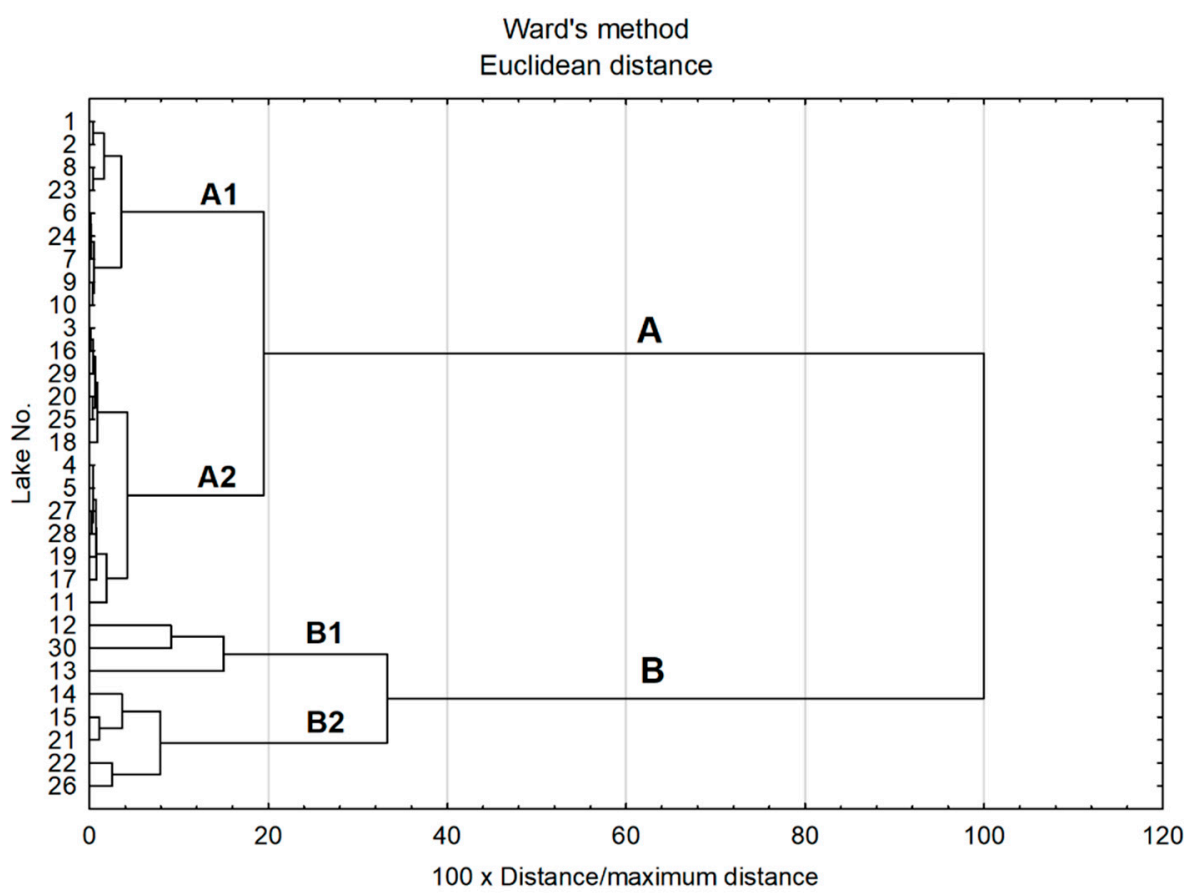

Figure 2. The results of cluster analysis based on physico-chemical parameters-a dendrogram (hierarchical tree) with marked clusters (A-A1, A2 and B-B1, B2).

In each of the main clusters, two subgroups of lakes were determined: A1 and A2, and B1 and B2. The characteristics of those lakes are shown in Table 1. The results of the Kruskal-Wallis test showed that almost all of the parameters analyzed (except for $\mathrm{Fe}^{3+}$, IC and $\mathrm{NO}_{3}{ }^{-}$) significantly differentiated among the distinguished subgroups. The post-hoc tests (presented as different letters in superscript) showed that subgroups A1 and A2 differ significantly in most (11 of 18) of the analyzed parameters (Table 1). Group A1 included lakes with the lowest visibility, highest $\mathrm{pH}$ values and lowest water mineralization. In this group there were also lakes with the highest concentration of nutrients, especially phosphorus.

Statistically significant differences in most parameters were also found between subgroups $\mathrm{B} 1$ and $\mathrm{B} 2$ (similarly to subgroups $\mathrm{A} 1$ and $\mathrm{A} 2,12$ out of 18 parameters). In these subgroups, no significant differences were found in terms of visibility (SD) and $\mathrm{pH}$, but they differed significantly in terms of mineralization and the concentrations of most analyzed elements. Group B1 included only three lakes with the most extreme conditions: the highest values of a complex of parameters connected with hardness and salinity. Furthermore, these lakes were characterized by the highest values of water color and very high concentrations of sulfur and iron. 
Table 1. Physico-chemical characteristics of the distinguished lake clusters. Mean values and standard deviations are given for all parameters. Different letters in superscript indicate significant $(p<0.05)$ group-to-group differences in the post-hoc test: the same letters = no differences; different letters = significant differences.

\begin{tabular}{|c|c|c|c|c|c|c|}
\hline Parameter & Unit & $\begin{array}{c}\text { Group A1 } \\
(n=9)\end{array}$ & $\begin{array}{c}\text { Group A2 } \\
(n=13)\end{array}$ & $\begin{array}{l}\text { Group B1 } \\
\quad(n=3)\end{array}$ & $\begin{array}{c}\text { Group B2 } \\
\quad(n=5)\end{array}$ & K-W Test \\
\hline SD & $\mathrm{m}$ & $1.5 \pm 0.6^{a}$ & $2.6 \pm 2.0^{a, b}$ & $3.2 \pm 0.9^{a, b}$ & $4.0 \pm 1.3^{b}$ & $p=0.02$ \\
\hline $\mathrm{pH}$ & & $7.1 \pm 0.4^{\mathrm{a}}$ & $5.7 \pm 1.6^{\mathrm{b}}$ & $2.8 \pm 0.1^{\mathrm{c}}$ & $3.3 \pm 0.5^{c}$ & $p<0.01$ \\
\hline $\mathrm{EC}$ & {$[\mu \mathrm{S} / \mathrm{cm}]$} & $139.1 \pm 41.1^{\mathrm{a}}$ & $321.5 \pm 52.2^{\mathrm{a}}$ & $1718.7 \pm 682.0^{b}$ & $862.0 \pm 214.4^{\mathrm{c}}$ & $p<0.01$ \\
\hline Salinity & [ppm] & $63.7 \pm 23.2^{\mathrm{a}}$ & $154.4 \pm 24.7^{b}$ & $1033.3 \pm 173.0^{c}$ & $423.0 \pm 108.1^{\mathrm{d}}$ & $p<0.01$ \\
\hline Hardness & {$\left[{ }^{\circ} \mathrm{dH}\right]$} & $2.9 \pm 1.5^{\mathrm{a}}$ & $6.8 \pm 1.4^{\mathrm{b}}$ & $28.1 \pm 12.1^{\mathrm{c}}$ & $14.1 \pm 1.5^{\mathrm{d}}$ & $p<0.01$ \\
\hline Color & {$[\mathrm{mg} \mathrm{Pt} / \mathrm{L}]$} & $25.5 \pm 32.7^{\mathrm{a}}$ & $7.6 \pm 7.2^{b}$ & $35.1 \pm 17.1^{\mathrm{a}}$ & $3.0 \pm 0.0^{b}$ & $p=0.02$ \\
\hline $\mathrm{Na}^{+}$ & {$\left[\mathrm{mg} \mathrm{L}^{-1}\right]$} & $3.09 \pm 1.27^{\mathrm{a}}$ & $7.05 \pm 1.98^{b}$ & $8.27 \pm 1.36^{b}$ & $7.39 \pm 2.70^{b}$ & $p<0.01$ \\
\hline $\mathrm{K}^{+}$ & {$\left[\mathrm{mg} \mathrm{L}^{-1}\right]$} & $4.33 \pm 2.3^{\mathrm{a}}$ & $6.01 \pm 1.73^{b}$ & $9.83 \pm 1.39^{c}$ & $7.62 \pm 0.89^{b, c}$ & $p<0.01$ \\
\hline $\mathrm{Ca}^{2+}$ & {$\left[\mathrm{mg} \mathrm{L}^{-1}\right]$} & $13.82 \pm 8.79^{a}$ & $36.9 \pm 8.46^{b}$ & $152.63 \pm 68.69^{c}$ & $72.92 \pm 9.64^{d}$ & $p<0.01$ \\
\hline $\mathrm{Mg}^{2+}$ & {$\left[\mathrm{mg} \mathrm{L}^{-1}\right]$} & $3.1 \pm 2.47^{\mathrm{a}}$ & $7.1 \pm 1.59^{b}$ & $29.0 \pm 10.71^{\mathrm{c}}$ & $16.88 \pm 0.99^{d}$ & $p<0.01$ \\
\hline $\mathrm{Cl}^{-}$ & {$\left[\mathrm{mg} \mathrm{L}^{-1}\right]$} & $6.09 \pm 1.45^{\mathrm{a}}$ & $10.61 \pm 5.11^{b}$ & $4.05 \pm 0.67^{\mathrm{a}}$ & $6.19 \pm 1.37^{\mathrm{a}}$ & $p<0.01$ \\
\hline $\mathrm{Fe}$ & {$\left[\mathrm{mg} \mathrm{L}^{-1}\right]$} & $0.95 \pm 2.23^{\mathrm{a}}$ & $0.61 \pm 0.5^{\mathrm{a}}$ & $89.37 \pm 55.68^{b}$ & $6.35 \pm 7.65^{a}$ & $p<0.01$ \\
\hline $\mathrm{Al}^{3+}$ & {$\left[\mathrm{mg} \mathrm{L}^{-1}\right]$} & $0.05 \pm 0.04^{\mathrm{a}}$ & $0.53 \pm 1.12^{\mathrm{a}}$ & $7.64 \pm 7.79^{b}$ & $2.11 \pm 3.25^{\mathrm{a}}$ & $p<0.01$ \\
\hline $\mathrm{Mn}^{2+}$ & {$\left[\mathrm{mg} \mathrm{L}^{-1}\right]$} & $0.12 \pm 0.15^{\mathrm{a}}$ & $0.4 \pm 0.24^{b}$ & $2.78 \pm 0.29^{c}$ & $1.23 \pm 0.38^{d}$ & $p<0.01$ \\
\hline $\mathrm{TC}$ & {$\left[\mathrm{mg} \mathrm{L}^{-1}\right]$} & $19.47 \pm 8.44^{\mathrm{a}}$ & $13.96 \pm 11.99^{\mathrm{a}, \mathrm{b}}$ & $1.84 \pm 0.94^{b, c}$ & $1.42 \pm 0.70^{c}$ & $p<0.01$ \\
\hline $\mathrm{TN}$ & {$\left[\mathrm{mg} \mathrm{L}^{-1}\right]$} & $1.2 \pm 0.51^{\mathrm{a}}$ & $0.83 \pm 0.71^{\mathrm{a}, \mathrm{b}}$ & $1.79 \pm 0.08^{\mathrm{a}, \mathrm{c}}$ & $0.57 \pm 0.34^{\mathrm{a}, \mathrm{b}}$ & $p=0.03$ \\
\hline $\mathrm{TP}$ & {$\left[\mathrm{mg} \mathrm{L}^{-1}\right]$} & $0.08 \pm 0.06^{\mathrm{a}}$ & $0.05 \pm 0.05^{\mathrm{a}, \mathrm{b}}$ & $0.01 \pm 0.01^{\mathrm{b}}$ & $0.02 \pm 0.03^{b}$ & $p=0.02$ \\
\hline TS & {$\left[\mathrm{mg} \mathrm{L}^{-1}\right]$} & $4.74 \pm 2.12^{\mathrm{a}}$ & $30.71 \pm 12.13^{b}$ & $317.33 \pm 36.12^{c}$ & $110.74 \pm 20.84^{d}$ & $p<0.01$ \\
\hline $\mathrm{Fe}^{3+}$ & {$\left[\mathrm{mg} \mathrm{L}^{-1}\right]$} & $0.13 \pm 0.15^{\mathrm{a}}$ & $0.19 \pm 0.27^{\mathrm{a}}$ & $86.97 \pm 75.15^{b}$ & $0.18 \pm 0.17^{\mathrm{a}, \mathrm{b}}$ & $p=0.15$ \\
\hline IC & {$\left[\mathrm{mg} \mathrm{L}^{-1}\right]$} & $9.34 \pm 7.88^{a}$ & $1.72 \pm 2.54^{b}$ & $0.53 \pm 0.30^{\mathrm{a}, \mathrm{b}}$ & $0.78 \pm 0.69^{a, b}$ & $p=0.09$ \\
\hline TOC & {$\left[\mathrm{mg} \mathrm{L}^{-1}\right]$} & $10.13 \pm 4.43^{\mathrm{a}}$ & $12.24 \pm 12.30^{\mathrm{a}, \mathrm{c}}$ & $1.31 \pm 0.64^{b, c}$ & $0.64 \pm 0.51^{\mathrm{b}}$ & $p<0.01$ \\
\hline $\mathrm{N}_{\text {org. }}$ & {$\left[\mathrm{mg} \mathrm{L}^{-1}\right]$} & $1.07 \pm 0.54^{\mathrm{a}}$ & $0.66 \pm 0.74^{\mathrm{a}, \mathrm{b}}$ & $0.12 \pm 0.14^{b}$ & $0.13 \pm 0.08^{b}$ & $p=0.02$ \\
\hline $\mathrm{NO}_{2}^{-}$ & {$\left[\mathrm{mg} \mathrm{L}^{-1}\right]$} & $0.03 \pm 0.06^{\mathrm{a}}$ & $0.00 \pm 0.01^{\mathrm{b}}$ & $0.00 \pm 0.00^{\mathrm{a}, \mathrm{b}}$ & $0.00 \pm 0.00^{\mathrm{a}, \mathrm{b}}$ & $p=0.02$ \\
\hline $\mathrm{NO}_{3}^{-}$ & {$\left[\mathrm{mg} \mathrm{L}^{-1}\right]$} & $0.02 \pm 0.03^{a}$ & $0.02 \pm 0.04^{\mathrm{a}}$ & $0.08 \pm 0.07^{\mathrm{a}}$ & $0.01 \pm 0.01^{\mathrm{a}}$ & $p=0.23$ \\
\hline $\mathrm{NH}_{4}^{+}$ & {$\left[\mathrm{mg} \mathrm{L}^{-1}\right]$} & $0.08 \pm 0.10^{\mathrm{a}}$ & $0.15 \pm 0.16^{\mathrm{a}}$ & $1.59 \pm 0.14^{b}$ & $0.43 \pm 0.34^{\mathrm{c}}$ & $p<0.01$ \\
\hline $\mathrm{SO}_{4}{ }^{2-}$ & {$\left[\mathrm{mg} \mathrm{L}^{-1}\right]$} & $12.09 \pm 5.59^{\mathrm{a}}$ & $99.17 \pm 54.81^{b}$ & $940.27 \pm 133.65^{c}$ & $444.02 \pm 162.26^{\mathrm{d}}$ & $p<0.01$ \\
\hline
\end{tabular}

\subsection{Macrophyte Differentiation}

The study showed great diversity of flora and vegetation in the studied lakes. A total of 73 plant species were found in the 30 studied lakes, including 68 vascular plants and 5 mosses. Macroscopic algae were not found in any of the lakes. The most numerous of the vascular plants species were helophytes, which occupied the shallowest positions. The species with the highest frequency in this group of lakes were Phragmites australis (24 lakes) and Juncus effusus (in 19 lakes). Out of the hydrophytes, the most frequent species was Nymphaea alba (in 17 lakes).

The lakes differed considerably in terms of the number of species present. The highest numbers of species were found in lakes located in the northern part of the Muskau Arch: number 4 (30 species), number 5 (27 species), number 18 (26 species) and number 20 (25 species). The lowest numbers of macrophytes were found in the lakes of the southern part of the area. Just one species was detected in lakes 12 and 13. A detailed list of species occurring in the lakes is presented in Supplementary Table S1.

The structure and diversity of vegetation communities largely reflected species variety. During the study we found a total of 30 communities, 29 of which had the rank of association (according to the phytosociological nomenclature). A detailed list of vegetation communities is presented in Supplementary Table S2. In most lakes, communities were very poorly developed (the median of the number of communities $=2$ ), and the dominant communities were reed bed ones, among which the most frequent was Phragmitetum communis (in 24 lakes). The hydrophyte communities occurred relatively rarely and were mostly represented by nympheids, with high prevalence of Nymphaeo albae-Nupharetum 
luteae (in 17 lakes). The highest number of communities (11) was found in lake number 4. In lakes 12 and 13 there were no communities.

The maximum depth range of vegetation occurrence in the studied lakes was between 0.1 and $9.0 \mathrm{~m}$. The smallest depth range was found in lakes with the lowest vegetation diversity: numbers 12 and 13 (up to $0.1 \mathrm{~m}$ ). In the southern part of the Muskau Arch there were also lakes with the largest maximum vegetation range. The highest value was found in lake number $29-9 \mathrm{~m}$.

The analyses showed that the identified groups (based on physico-chemical characteristics) also differed significantly in terms of all the biological parameters: the number of species, number of communities, maximum range of vegetation occurrence and chlorophylla (Figure 3). In the case of number of communities, the highest values were found in the lakes from group A2, and the lowest in group B1. It is also worth noting that in two lakes in group $\mathrm{B} 1$ there was not a single vegetation community. In the three remaining groups (A1, A2 and B2) there was great divergence between the extreme values. The most uniform in terms of the number of communities were lakes in groups A1 and B2.
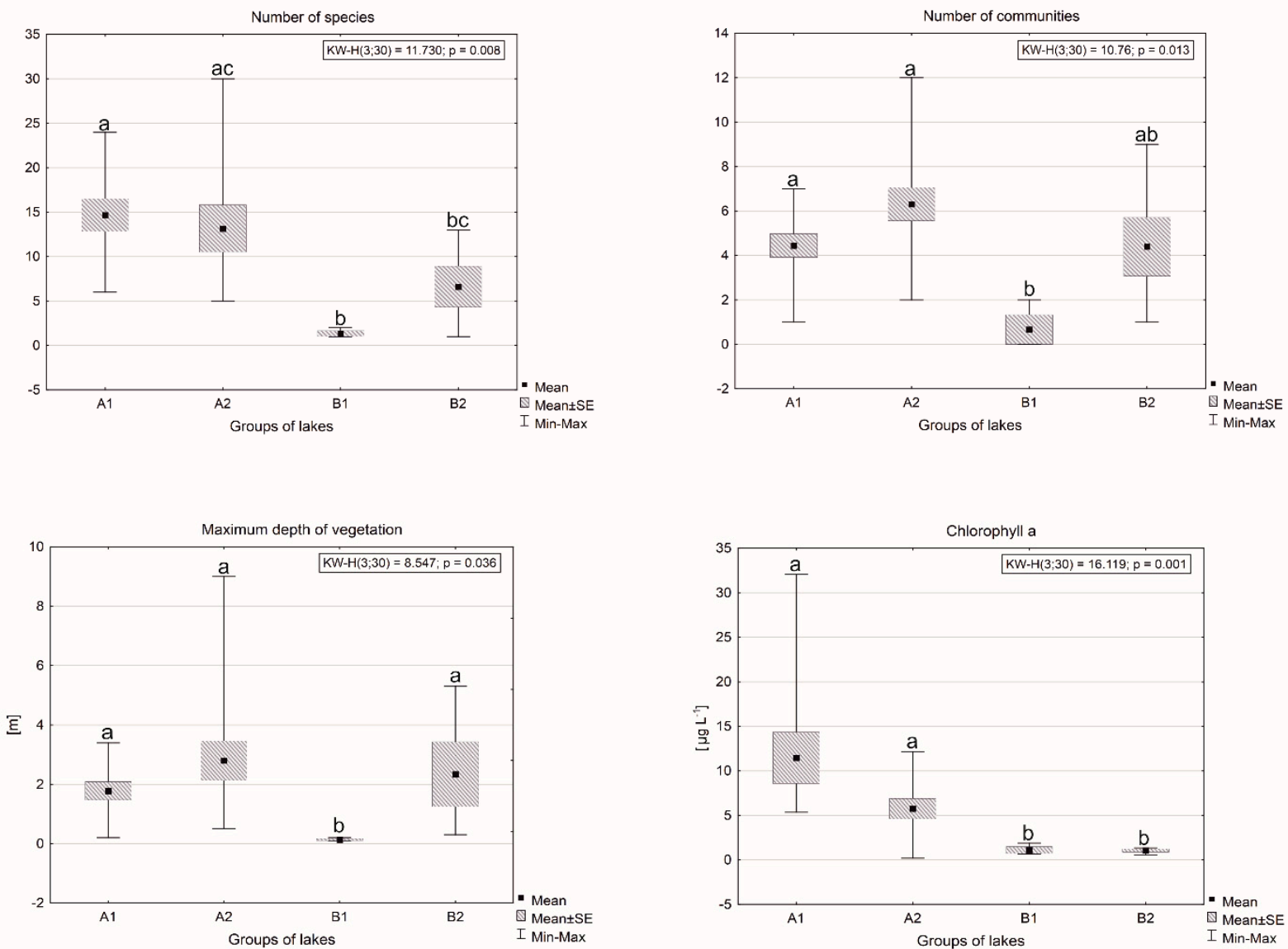

Figure 3. Differentiation of the number of species, number of communities, maximum vegetation range and chlorophyll-a against distinguished groups of lakes. Different letters above the box and whisker plots indicate significant $(p<0.05)$ group-to-group differences: the same letters = no differences; different letters = significant differences.

The differences in number of species between lakes of different groups largely reflected the variety between groups A and B in the number of communities, although no statistically significant differences were found between groups A2 and B2. In this case the lowest number of species was also found in group B1 (1-2 species). The highest mean values (14 species) were found in group A1, although the maximum numbers of species (30, 27 and 25) occurred in lakes from group A2. Again, the lowest values, not exceeding several dozen centimeters of depth, were found in lakes from group B1. It is the only group that 
differs statistically significantly from others regarding this parameter. In all cases there were clear differences between the two main groups, A and B. In the other groups of lakes, the vegetation occurred from the depth of several dozen centimeters up to several meters, indicating great variety. The highest values of maximum range were found in lakes from group A2. Interestingly, in group B2 both the mean and the maximum values of range were higher than in group A1.

The variation in chlorophyll-a values among the groups significantly differed from the variation in maximum occurrence of vegetation and the two remaining biological parameters. In this case, groups B1 and B2 had the lowest, very uniform values $\left(<1.9 \mu \mathrm{g} \mathrm{L}^{-1}\right)$. The highest values were found in group A1 (the mean-11.5 $\left.\mu \mathrm{g} \mathrm{L}^{-1}\right)$ and A2 $\left(5.6 \mu \mathrm{g} \mathrm{L}^{-1}\right)$.

Out of the considered characteristics of vegetation, the most statistically significant correlations with habitat characteristics (physico-chemical parameters and additional ones) were found for the number of species: $24 / 31$ parameters (Table 2). It was most positively correlated with $\mathrm{pH}\left(\mathrm{r}_{\mathrm{s}}=0.82\right)$. Apart from $\mathrm{pH}$, in the group of physico-chemical parameters, positive correlations over the value of $\mathrm{r}_{\mathrm{s}}=0.5$ were also found for $\mathrm{Cl}, \mathrm{TC}, \mathrm{IC}, \mathrm{NO}_{2}{ }^{-}$and $\mathrm{N}_{\text {org }}$. Moreover, a positive correlation was found for chlorophyll-a. The majority of the remaining parameters were negatively correlated with the number of species. These were parameters connected with high water mineralization, such as EC, salinity, Fe and TS. The highest values were found for $\mathrm{Al}$ and $\mathrm{Mn}\left(\mathrm{r}_{\mathrm{s}}=-0.81\right.$ and $\mathrm{r}_{\mathrm{s}}=-0.72$, respectively) and for $\mathrm{NH}_{4}{ }^{+}$and TS $(-0.70$ and -0.60 , respectively). Out of the additional parameters, a high positive correlation $\left(r_{s}=0.73\right)$ was found for the age of the lakes. Interestingly, this parameter was not strongly correlated $\left(r_{s}<0.5\right)$ with the number of communities. As regards the morphometric characteristics, a negative correlation was found with the maximum depth. In the case of the other two variables characterizing vegetation, there were only single statistically significant correlations for which $r_{s}>0.5$ : for the number of communities $-\mathrm{Cl}^{-}$, and for the maximum depth of occurrence, Fe and TN.

Table 2. Spearman's rank correlations $\left(\mathrm{r}_{\mathrm{s}}\right)$ between habitat properties and macrophyte characteristics. * Significant correlations at the significance level of $p<0.05$.

\begin{tabular}{cccc}
\hline Variables & $\begin{array}{c}\text { Number of } \\
\text { Communities }\end{array}$ & Number of Species & $\begin{array}{c}\text { Max Depth of } \\
\text { Vegetation }\end{array}$ \\
\hline Max depth & -0.32 & $-0.57^{*}$ & 0.11 \\
\hline Area & $0.37^{*}$ & -0.04 & 0.25 \\
\hline Age & $0.41^{*}$ & $0.73^{*}$ & -0.03 \\
\hline $\mathrm{SD}$ & -0.31 & $-0.63^{*}$ & 0.15 \\
\hline $\mathrm{pH}$ & $0.37^{*}$ & $0.82^{*}$ & 0.23 \\
\hline $\mathrm{EC}$ & -0.15 & $-0.60^{*}$ & -0.23 \\
\hline $\mathrm{Salinity}$ & -0.15 & $-0.60^{*}$ & -0.24 \\
\hline $\mathrm{O}_{2}$ & -0.02 & 0.05 & 0.19 \\
\hline $\mathrm{Color}$ & -0.08 & 0.18 & -0.35 \\
\hline $\mathrm{Na}^{+}$ & 0.23 & -0.18 & -0.09 \\
\hline $\mathrm{K}^{+}$ & -0.15 & $-0.37^{*}$ & $-0.49 *$ \\
\hline $\mathrm{Ca}^{2+}$ & -0.11 & $-0.47^{*}$ & -0.33 \\
\hline $\mathrm{Mg}^{2+}$ & -0.17 & $-0.43^{*}$ & $-0.41 *$ \\
\hline $\mathrm{Cl}^{-}$ & $0.68 *$ & $0.63^{*}$ & -0.29 \\
\hline $\mathrm{Fe}^{3+}$ & -0.27 & $-0.50^{*}$ & $-0.56^{*}$ \\
\hline $\mathrm{Fe}^{3+}$ & -0.19 & -0.31 & -0.09 \\
\hline $\mathrm{Al}^{3+}$ & -0.33 & $-0.81^{*}$ & \\
\hline
\end{tabular}


Table 2. Cont.

\begin{tabular}{cccc}
\hline Variables & $\begin{array}{c}\text { Number of } \\
\text { Communities }\end{array}$ & Number of Species & $\begin{array}{c}\text { Max Depth of } \\
\text { Vegetation }\end{array}$ \\
\hline $\mathrm{Mn}^{2+}$ & -0.31 & $-0.72^{*}$ & -0.34 \\
\hline $\mathrm{TC}$ & 0.29 & $0.58^{*}$ & -0.09 \\
\hline $\mathrm{IC}$ & 0.22 & $0.51^{*}$ & 0.10 \\
\hline $\mathrm{TOC}$ & 0.31 & $0.45^{*}$ & -0.09 \\
\hline $\mathrm{TN}$ & -0.19 & 0.09 & $-0.58^{*}$ \\
\hline $\mathrm{N}_{\text {org. }}$ & 0.25 & $0.58^{*}$ & -0.24 \\
\hline $\mathrm{NO}_{2}{ }^{-}$ & 0.14 & $0.50 *$ & 0.12 \\
\hline $\mathrm{NO}_{3}{ }^{*}$ & -0.11 & -0.10 & -0.17 \\
\hline $\mathrm{NH}_{4}{ }^{+}$ & -0.47 & $-0.70 *$ & -0.30 \\
\hline $\mathrm{TP}^{*}$ & 0.22 & $0.45^{*}$ & -0.20 \\
\hline $\mathrm{TS}^{*}$ & -0.22 & $-0.60 *$ & -0.23 \\
\hline $\mathrm{SO}_{4}$ & -0.16 & $-0.53^{*}$ & -0.21 \\
\hline Hardness & -0.10 & $-0.43^{*}$ & -0.34 \\
\hline Chlorophyll a & 0.31 & $0.59^{*}$ & 0.05 \\
\hline
\end{tabular}

Significant correlations with most physico-chemical properties suggest a close relationship between the amount of macrophytes and water properties. The analysis of correlations showed that an increase in $\mathrm{pH}$ is accompanied by a decrease in water mineralization, which was proven not only by a negative correlation with conductivity, but also by decreasing content of sulfates, $\mathrm{NH}_{4}{ }^{+}, \mathrm{Mn}^{2+}$ or $\mathrm{Al}^{3+}$. In addition, an increase in lake age is related to growing concentration of nutrients (TC, TP, TN), which is accompanied by growth in chlorophyll-a concentration and lower visibility.

\section{Discussion}

\subsection{Differentiation of Water Properties}

Our research showed that the lakes have significant differences in terms of physicochemical parameters. As compared to previous studies [4], the use of a broad set of parameters in the cluster analysis allowed more detailed grouping of lakes against water chemistry and further interpretation of the differentiation against vegetation. The analyses carried out showed that the acidity of the water is of great importance here. Water acidity seems to be the key factor for chemical diversity, especially for the amounts of mineral substances in the waters of lignite lakes of Muskau Arch. This is in agreement with previous reports in general ([11] and literature quoted therein), for reports on this area in particular [19]. This specificity mostly depends on the oxidation of ferrous sulfidic compounds, which causes the release of considerable amounts of free mineral acids. The process is strengthened by the supply of groundwater, which washes out sulfides from the surrounding ground, causing their oxidation. The resulting effect is not only permanent water acidity but also higher iron concentration, hardness and free carbonic acid concentration [20]. Such extreme conditions occurred in group B, which was distinguished in cluster analysis. According to Pietssch [21] the group includes lakes that can be classified as "waters of the early stage" (Figure 4a). It seems to be confirmed also by the fact that these lakes are the youngest in the studied group (Pukacz et al., 2018). That particularly refers to group $\mathrm{B} 1$, i.e., lakes with the lowest $\mathrm{pHs}$ and the highest values of conductivity and hardness. These characteristics (especially low $\mathrm{pH}$ ) are undoubtedly significant for the biocenoses therein, including the vegetation $[8,9,22]$. The differences between this group and $\mathrm{B} 2$ mostly result from the concentrations of particular ions (i.a., $\mathrm{Fe}, \mathrm{Al}^{3+}, \mathrm{Ca}^{2+}$ and $\mathrm{Mg}^{2+}$ ). They are probably the consequences of the amount of sulfide minerals in the 
surrounding mine wastes, resulting from previously extracted material [12. In all lakes of group B2, clay and quartz were extracted in addition to lignite ([4] and references quoted therein), which also contributes to their characteristic turquoise color (Figure $4 b$ ).
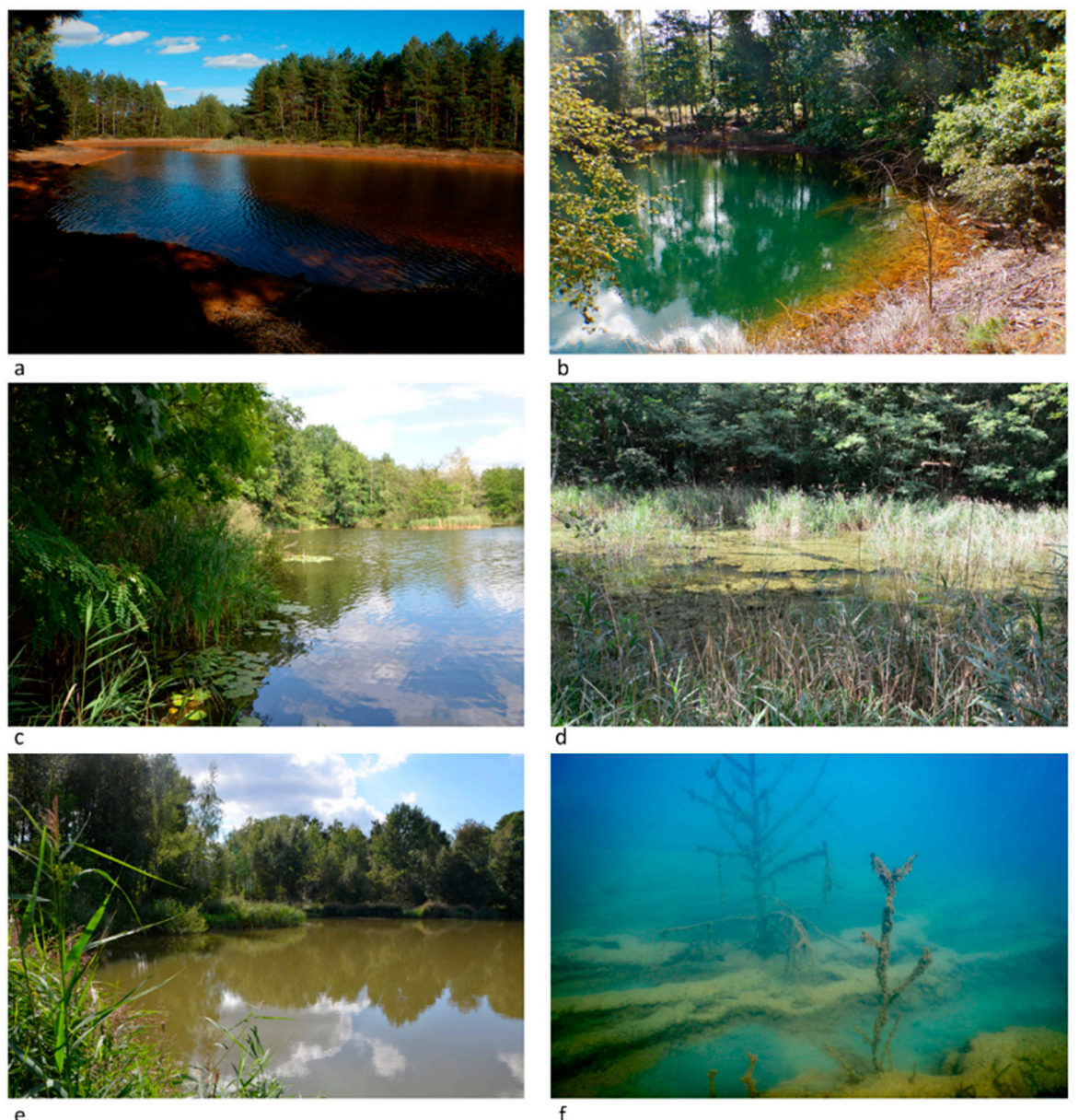

Figure 4. Examples of the investigated lakes: (a) an early stage lake (reddish-brown, extreme acidity, high mineralization with extreme iron content, no vegetation), (b) an early stage lake (clear water, turquoise color, very high acidity, lower iron content, monodominant species stands composed of hydrophytes), (c) a transitional stage lake (relatively low acidity, lower mineralization, higher nutrient content, well-developed stripe-like vegetation), (d) a late stage lake (neutral acidity, low hardness, high nutrient concentration, macrophyte overgrowth processes), (e) a degraded lake (neutralization with lime, fertilization with sewage, lack of hydrophytes as a consequence of carp stocking), (f) a sinkhole lake with a dead bottom zone and visible concentrations of hydrogen sulfide (dead trees-evidence of an earlier, terrestrial stage).

Opposite conditions occurred in the lakes from group A, including lakes with clearly lower acidity and lower values of the complex of parameters associated with hardness. These characteristics were also used to distinguish subgroups A1 and A2. Most of these lakes can be classified as "waters of the transitional stage" (Figure 4c). This is due to the progressive neutralization of water, which is largely the result of natural chemical processes leading to gradual flocculation and sedimentation of ions dissolved in water [12]. Furthermore, under the influence of hydrochemical changes, associated, i.a., with processes of secondary succession and the management of the drainage area, lakes finally become similar to natural ecosystems [1]. In normal conditions, not distorted by any extra factors, these changes take place very slowly [1,23], which is confirmed by the fact that in some lakes from this group (i.a., 27, 28 and 29), values of $\mathrm{pH}<3.5$ were observed. 
Some lakes from group A, especially A1, can be classified as "waters of the late stage," wherein the $\mathrm{pHs}$ are similar to neutral, and hardness values and the concentrations of particular ions are the lowest. This is mostly related to the processes of aging, causing i.a., the binding of sulfuric acid and gradual sedimentation of mineral compounds [24]. In the case of these lakes, relatively high values of water color were also found. However, in contrast to lakes from group B1, where the color is mainly the effect of high concentrations of iron compounds, in these lakes it is mainly the effect of increased trophy, which results in high concentrations of tannins and humic substances. However, some of these lakes are relatively young ( $<90$ years old), [4], especially near the village of Trzebiel (e.g., lakes numbered 9, 10, 23 and 24). In this case, their current condition is related to human activity, which was indicated by previous works too-i.a., Sienkiewicz, Gasiorowski [1] and Oszkinis-Golon et al. [3]. Human activity particularly refers to water neutralization, which was carried out by humans in the second half of the 20th century in order to restock the lakes within the Muskau Arch [4]. In the case of post-mining lakes, the most often used substance is calcium hydroxide (there is no specific data on what amounts are used in lakes). Apart from that, sometimes biological neutralization is used to accelerate biological production [25]. The process of water neutralization initiated by humans is very quick and hard to reverse, especially when the $\mathrm{pH}$ exceeds 4.5 [26]. Still, even after many years, the chemical specificity of those lakes is clearly different from natural, hard water post-glacial lakes from this area, whose water chemistry is mainly determined by the carbonate-calcium equilibrium and trophy factors, often induced anthropogenically [27].

\subsection{Macrophyte Differentiation}

The results of macrophyte analysis, both the number of species and for the number of communities, largely reflected the diversity of lakes against the background of physicochemical parameters. In lakes with the most extreme conditions ("waters of the early stage") we found the lowest numbers of species and just single communities of reed bed vegetation. Species occurring in these lakes (Juncus effusus and Phragmites australis) can only be found in the shallow littoral zone (Figure 5a). In light of previous literature [21,28], they should be classified as pioneer species, most resistant to extreme conditions. This zone particularly refers to water with reddish-brown color, extreme acidity, high mineralization and extreme iron content particularly (all lakes of subgroup B1), which prevent the development of hydrophytes and restrict secondary succession. Apart from these parameters, nutrient availability (low values of bioavailable forms in the entire group B) and heavy metal toxicity [29] are also limiting factors, which was confirmed by the correlations obtained. The ability of these helophytes to survive in such extreme conditions is due to the fact that their development is not only dependent on the water chemistry, but also on the substrate conditions. These conditions may still be relatively favorable and buffer extreme conditions in the water column. In addition, littoral conditions may differ from those in the pelagial zone. This is a considerable difference to hydrophytes.

On the other hand, among the most extreme lakes (in group B2) there are also lakes (e.g., number 21, 14 and 15), where there are monodominant species stands composed of hydrophytes apart from well-developed reed beds. Although these lakes did not differ statistically significantly from group B1 in terms of $\mathrm{pH}$, they had lower values of mineralization $\left(\mathrm{EC}<840.0 \mu \mathrm{Scm}^{-1}\right.$, total hardness $<16.0^{\circ} \mathrm{dH}$ ), and lower concentrations of iron, aluminum and sulfur ( $<4.0 \mathrm{mg} \mathrm{L}^{-1},<2.0$ and $<120 \mathrm{mg} \mathrm{L}^{-1}$, respectively). In light of the current literature, these must be regarded as the boundary values for the development of pioneer hydrophytes $[28,30]$. They do not only include species such as Juncus Bulbosus or Sphagnum cuspidatum (submerged forms), which have already been found in waters with similar parameters, but also to Nymphaea alba and Potamogeton natans, for which these values have never been observed before (Figure $5 b-d$ ). These species also occupied relatively deep sites because of water transparency, which was very high in comparison to lakes from group B1 (>3.8 m). Apart from much lower concentrations of sulfur and iron compounds, this is also a consequence of very low concentrations of chlorophyll-a $\left(<1.3 \mu \mathrm{g} \mathrm{L}^{-1}\right)$, which 
did not exceed values characteristic for ultra-oligotrophy in the entire B2 group [31,32]. Interestingly, in two lakes from this group (14 and 15), fish of the species Tinca tinca L. were observed during the survey, although in light of contemporary literature, such low $\mathrm{pH}$ values make their reproduction and development impossible ([33] and literature quoted therein). This subject definitely needs more research.

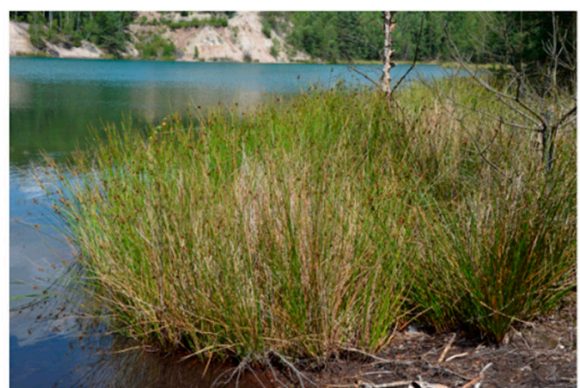

a

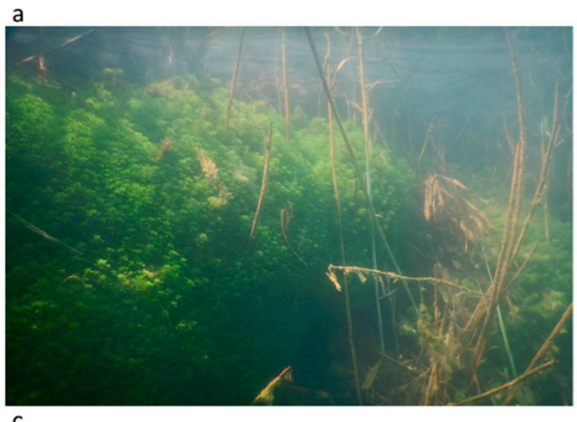

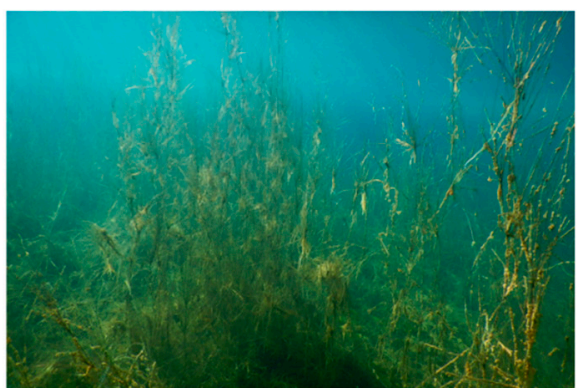

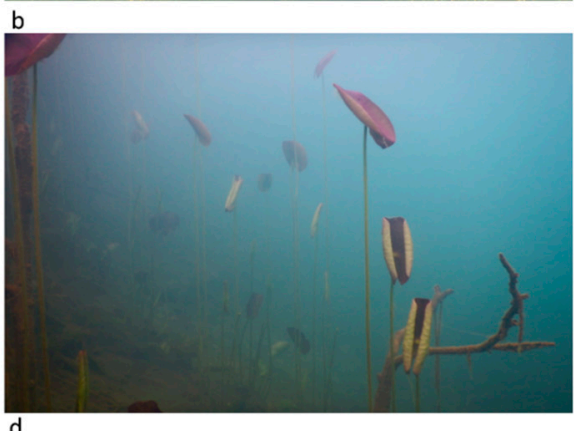

Figure 5. Examples of vegetation typical for the lakes: (a) Juncus effusus, (b) a submerged form of Juncus bulbosus, (c) a submerged form of Sphagnum cuspidatum, (d) juveniles of Nymphaea alba.

In contrast to lakes from group B, the conditions found in lakes from group A were much more favorable for vegetation development: mainly much lower water acidity and lower mineralization, particularly in the lakes from subgroup A1. The waters of these lakes were also characterized by clearly higher trophic states (higher concentrations of bioavaliable nutrient forms), which explains the highest concentrations of chlorophyll-a and the related low visibility. Apart from the "resistant" reed bed species found in lakes from group B, in these lakes there were also many new hydrophyte species, which formed a classic belt-shaped system typical of natural lakes. In many pit lakes the numbers of species and of communities were similar to those in eutrophic lake ecosystems in the region [27].

Greater diversity of species and communities of macrophytes (particularly hydrophytes) in these lakes is largely connected with natural succession processes. It was observable in the case of small and shallow lakes (e.g., lakes number 1, 2 and 23), where advanced overgrowth processes occurred. In many cases (e.g., lakes number 5, 6, 23 and 24), this process is greatly accelerated by the above-mentioned procedures of water neutralization and fertilization. In addition, in some lakes (e.g., number 6, 7, 9, 10 and 20), very high degradation of hydrophytes was observed, which was a consequence of inappropriate fishery, especially the introduction of the grass carp and common carp (Figure 4e).

It is worth noting that the diversity of numbers of species and communities to a great extent reflects the locations and ages of the lakes. Lakes from group A1, displaying the highest diversity of species and communities, are located in the northern part of the studied area and belong to the oldest pit lakes in the Muskau Arch. [4]. In group B2, contrasting in terms of flora and fauna, there were the youngest lakes, located in the central and southern part of the area. As shown by a previous study [3], the genesis and the former way of extraction are very important to understanding the differences between these lakes, as they had an impact, i.a., on the formation of their bathymetric structure. Many of the lakes are sink hole lakes formed in former underground mining pits, and unlike natural lakes and 
open pit lakes, their depths may increase with time. This is accompanied by geochemical transformations (Figure 4f) and may have an important influence on successive processesi.a., the range of vegetation occurrence [5,6]. Firstly, by increasing the depth, secondary acidification of the water can occur (analogous to processes occurring in the initial phase of lake development). Secondly, increasing depth limits the vertical extent of vegetation and its contribution to the bottom area. The former way of extraction may also have had another impact on the development of biocenoses-varying the amount of organic matter available. Open-pit mining leads to more exposure to bare soil (including minerals), whereas sinkhole lakes can lead to more exposure to organic soil (i.e., top layers of the former terrestrial environment). As such, there can be more nutrients available when sinkhole lakes develop, which can speed up the development of algae populations and higher trophic levels, including plants.

In the case of a high positive correlation between the lake age and the number of species, the explanation may be the changing water chemistry: lake aging is associated with increasing $\mathrm{pH}$ and decreasing water mineralization, including the concentration of sulfates, $\mathrm{NH}_{4}{ }^{+}, \mathrm{Mn}^{2+}$ or $\mathrm{Al}^{3+}$. In addition, the concentration of nutrients (TC, TP, TN) also grows, which is accompanied by higher chlorophyll-a concentration and lower visibility. All these processes naturally promote macrophyte succession. However, this was not confirmed by the very few significant correlations for the number of communities, which suggests that the diversity of communities displays lower sensitivity to habitat conditions than the number of species. On the one hand, it may mean that only a few species are able to form stable populations. At the same time, just like in the case of natural lakes, the conditions caused by concentrating macrophyte biomass and changing local habitat conditions are favorable for the occurrence of new species [34]. On the other hand, natural geochemical changes have been accompanied by anthropogenic influences, which may have contributed to the relatively low number of correlations.

\section{Conclusions}

The survey carried out showed that Muskau Arch lakes are characterized by high habitat diversity, which is also reflected in the quantitative and qualitative structure of macrophytes. We may conclude that the processes of secondary succession observed in lakes for decades are determined mainly by water chemistry and that $\mathrm{pH}$ and water mineralization are of the key importance. Additional factors are the morphometric structures and ages of the lakes. On the one hand, these factors greatly limit the development of biocenoses and are responsible for a very sharp lake-to-lake variation. Thus, we can distinguish macrophyte groups characteristic of particular physical and chemical conditions of water. It is worth emphasizing that some of the species found are able to survive in extreme conditions not recorded previously in the literature. On the other hand, in some lakes a gradual mitigation and stabilization of the habitat conditions leads to the development of biocenoes similar to natural ones.

An additional, unfavorable factor affecting natural macrophyte diversity is the conversion of lakes for commercial use, mainly fishing. The actions taken by local people (neutralization and fertilization) lead to irreversible changes in water chemistry, which also adversely affect the entire ecosystem. This can result in excessive growth of algae, which limits the development of hydrophytes and leads to loss of species diversity. These negative shifts were largely reflected by the results of the macrophyte analyses carried out. Even though the formation of post-mining lakes is a result of earlier anthropogenic pressures in the area, the new ecosystems developed over many years now constitute a unique element of the landscape that should be subject to special protection.

Supplementary Materials: The following are available online at https:/ / www.mdpi.com/article/10 .3390/w13202909/s1. Table S1: The list of macrophyte species occurring in the Muskau Arch lakes; Table S2: The list of vegetation communities occurring in the Muskau Arch lakes. 
Author Contributions: Conceptualization, A.P.; methodology and investigation, A.P., M.O.-G. and M.F.; data analysis, A.P., M.O.-G. and M.F.; writing-original draft preparation, A.P. and M.O.-G. writing-review and editing, A.P. and M.O.-G. All authors have read and agreed to the published version of the manuscript.

Funding: The APC was funded by Adam Mickiewicz University and University of Zielona Góra. The research received no external funding.

Institutional Review Board Statement: Not applicable.

Informed Consent Statement: Not applicable.

Data Availability Statement: The data presented in this study are available on request from the corresponding author.

Acknowledgments: We wish to thank Jacek Koźma for support in data acquisition and interpretations. We are also grateful to the anonymous reviewers and the editor for their comments and suggestions for improving the manuscript.

Conflicts of Interest: The authors declare no conflict of interest.

\section{References}

1. Sienkiewicz, E.; Gasiorowiski, M. The evolution of a mining lake-From acidity to natural neutralization. Sci. Total Environ. 2016, 557-558, 343-353. [CrossRef]

2. Blanchette, M.L.; Lund, M.A. Pit lakes are a global legacy of mining: An integrated approach to achieving sustainable ecosystems and value for communities. Curr. Opin. Environ. Sustain. 2016, 23, 28-34. [CrossRef]

3. Oszkinis-Golon, M.; Jerzak, L.; Frankowski, M.; Pukacz, A. Physicochemical Differentiation of the Muskau Arch Pit Lakes in the Light of Long-Term Changes. Water 2020, 12, 2368. [CrossRef]

4. Pukacz, A.; Oszkinis-Golon, M.; Frankowski, M. The physico-chemical diversity of pit lakes of the Muskau Arch (Western Poland) in the context of their evolution and genesis. Limnol. Rev. 2018, 18, 115-126. [CrossRef]

5. Koźma, J. Anthropogenic landscape changes connected with the old brown coalmining based on the example of the Polish part of the Muskau Arch area. Górnictwo Odkryw. 2016, 57, 1-13.

6. Schultze, M.; Boehrer, B. Development of Two Meromictic Pit Lakes—a Case Study from the Former brown coal Mine MerseburgOst, Germany. In Proceedings of the 10th IMWA Congress: Mine Water and the Environment, Karlovy Vary, Czech Republic, 2-5 June 2008; pp. 611-614.

7. Kasztelewicz, Z. Pros and cons of coal mining in Poland. Polityka Energetyczna 2012, 15, 7-27.

8. Koschorreck, M.; Tittel, J. Benthic photosynthesis in an acidic mining lake (pH 2.6). Limnol. Oceanogr. 2002, 47, 1197-1201. [CrossRef]

9. Moser, M.; Weisse, T. The most acidified Austrian lake in comparison to a neutralized mining lake. Limnologica 2011, 41, 303-315. [CrossRef]

10. Nixdorf, B.; Uhlmann, W.; Lessmann, D. Potential for remediation of acidic mining lakes evaluated by hydrogeochemical modelling: Case study Grunewalder Lauch (Plessa 117, Lusatia/Germany). Limnologica 2010, 40, 167-174. [CrossRef]

11. Geller, W.; Klapper, H.; Schultze, M. Natural and Anthropogenic Sulphuric Acidification of lakes. In Acidic Pit Lakes, Acid Main Drainage, Limnology and Reclamation; Geller, W., Schultze, M., Kleinmann, B., Wolkersdorfer, C., Eds.; Springer: Berlin/Heidelberg, Germany, 1998; pp. 3-15.

12. Peine, A.; Peiffer, S. In-Lake Neutralization of Acid Mine Lakes. In Acidic Pit Lakes, Acid Main Drainage, Limnology and Reclamation; Geller, W., Schultze, M., Kleinmann, B., Wolkersdorfer, C., Eds.; Springer: Berlin/Heidelberg, Germany, 1998 ; pp. 47-64.

13. Van den Berg, M.S.; Coops, H.; Meijer, M.-L.; Scheffer, M.; Simons, J. Clear water associated with a dense Charavegetation in the shallow and turbid lake Veluwemeer. The Netherlands. In The Structuring Role of Submerged Macrophytes in Lakes; Springer: New York, NY, USA, 1998; pp. 339-352.

14. Srivastava, J.; Gupta, A.; Chandra, H. Managing water quality with aquatic macrophytes. Rev. Environ. Sci. Biotechnol. 2008, 7, 1-255. [CrossRef]

15. Naiman, R.J.; Decamps, H. The Ecology and Management of Aquatic-Terestrial Ecotones; UNESCO/MAB(05)/M2/v.4: Paris, France, 1990; pp. 7-294.

16. Matejczuk, W. Plankton poeksploatacyjnych zbiorników wodnych z rejonu Trzebiela (Plankton of pit lakes in the mining excavations in Trzebiel area), [in:] Radkiewicz J. (red.). Przyr. Środk. Nadod. 1989, 1, 93-118, (In Polish, English Summary).

17. Fukrek, F. Fitosocjologia (Phytosocjology) Państwowe Wydawnictwa Rolnicze i Leśne; 1967; pp. 1-218. (In Polish)

18. Golterman, H.L.; Clymo, R.S. Methods for Chemical Analysis of Freshwaters; Blackwell Scientific Publications: Oxford, UK; Edinburgh, UK, 1969; pp. 1-172.

19. Lutyńska, S.; Labus, K. Identification of processes controlling chemical composition of pit lakes waters located in the eastern part of Muskau Arch (Polish-German borderland). Arch. Environ. Prot. 2015, 41, 60-69. [CrossRef] 
20. Friese, K.; Hupfer, M.; Schultze, M. Chemical Characteristics of Water and Sendiment in Acid Mining Lakes of the Lusatian Lignite District. In Acidic Pit Lakes, Acid Main Drainage, Limnology and Reclamation; Geller, W., Schultze, M., Kleinmann, B., Wolkersdorfer, C., Eds.; Springer: Berlin/Heidelberg, Germany, 1998; pp. 25-45.

21. Pietsch, W. Colonization and Development of Vegetational in Mining Lakes of the Lusatian Lignite Area in Dependence on Water Genesis. In Acidic Pit Lakes, Acid Main Drainage, Limnology and Reclamation; Geller, W., Schultze, M., Kleinmann, B., Wolkersdorfer, C., Eds.; Springer: Berlin/Heidelberg, Germany, 1998; pp. 169-196.

22. Jędrczak, A.; Jachimko, B.; Najbar, B. Zmiany fizyczno- chemicznych cech wód największego zbiornika meromiktycznego na pojezierzu antropogenicznym w okresie kilkunastu lat (Changes in the physico-chemical properties of water in the largest meromictic pit lakes in the anthropogenic Lakeland over a dozen years). Zesz. Nauk. Politech. Zielonogórskiej-Inżynieria Sr. 1998, 116, 5-17, (In Polish, English Summary).

23. Schultze, M. Limnology of Pit Lakes. In Acidic Pit Lakes, The Legacy of Coal and Metal Surface Mines; Geller, W., Schultze, M., Kleinmann, B., Wolkersdorfer, C., Eds.; Springer: Berlin/Heidelberg, Germany, 1998; pp. 23-224.

24. Schultze, M.; Geller, W. The acid lakes of the lignite mining district of the former German Democratic Republic. In Geochamical approaches to environmental engineering of metals; Reuther, R., Ed.; Environmental Science Series; Springer: Berlin/Heidelberg, Germany; New York, NY, USA, 1996; pp. 89-105.

25. Wendt-Potthoff, K.; Frommichen, R.; Herzsprung, P.; Koschorreck, M. Microbial Fe(III) reduction in acidic mining lake sediments after addition of an organic substrate and lime. Water Air Soil Pollut. 2002,1-16.

26. Brugam, R.B.; Gastineau, J.; Ratcliff, E. The neutralization of acidic coal mine lakes by addition of natural organic matter: A mesocosm test. Hydrobiologia 1995, 316, 153-159. [CrossRef]

27. Pukacz, A.; Pełechaty, M.; Pełechata, A.; Siepak, M.; Niedzielski, P. Phytocoenotic differentiation of Lubuskie Lakeland lakes as related to the habitat properties. Limnol. Rev. 2005, 5, 223-229.

28. Fyson, A. Angiosperms in acidic waters at pH 3 and below. Hydrobiologia 2000, 433, 129-135. [CrossRef]

29. Whitton, B.A.; Diaz, B.M. Influence of environmental factors on photosynthetic species composition in highly acidic waters. Verh. Int. Ver. Limnol. 1981, 21, 1459-1465. [CrossRef]

30. Sand-Jensen, K.; Rasmussen, L. Macrophytes and chemistry of acidic streams from lignite mining areas. Bot. Tidskr. 1978, 72, 105-112.

31. Forsberg, C.; Ryding, S.-O. Eutrophication parameters and trophic state indices in 30 Swedish waste-receiving lakes. Arch. Hydrobiol. 1980, 89, 189-207.

32. Vollenweider, R.A.; Kerekes, J. Eutrophication of Waters. Monitoring, Assessment and Control; OECD: Paris, France, $1982 ;$ pp. 1-156.

33. Duis, K. Toxicity of Acidic Post-Mining Lake Water to Early Life Stages of Tench, TincaTinca (Cyprinidae). Water Air Soil Pollut. 2001, 132, 373-388. [CrossRef]

34. Larcher, W. Physiological Plant Ecology. In Ecophysiology and Stress Physiology of Functional Groups; Springer: New York, NY, USA, 2003; pp. 1-450. 